\title{
LSP and culture: a special relationship
}

\section{Ann M. Johns}

\section{OpenEdition}

\section{Journals}

Electronic version

URL: http://journals.openedition.org/asp/4002

DOI: 10.4000/asp.4002

ISSN: 2108-6354

\section{Publisher}

Groupe d'étude et de recherche en anglais de spécialité

\section{Printed version}

Date of publication: 1 December 1994

Number of pages: 11-19

ISSN: 1246-8185

\section{Electronic reference}

Ann M. Johns, « LSP and culture: a special relationship », ASp [Online], 5-6 | 1994, Online since 20

November 2013, connection on 02 May 2019. URL : http://journals.openedition.org/asp/4002 ; DOI :

$10.4000 / a s p .4002$

This text was automatically generated on 2 May 2019.

Tous droits réservés 


\title{
LSP and culture: a special relationship
}

\author{
Ann M. Johns
}

I am an American, coming to France to talk about language and culture, to a nation where even the politicians are expected to recite poetry and enjoy the opera! The French are famous for bringing their interest in culture and language wherever they go: to the classroom and in their travels. We learn that the first French explorers in 16th century North America, for example, immediately began to study the cultures and languages of the Native Americans. Jacques Cartier brought two Indians to France so that they could be studied in depth; Champlain and his crew were particularly interested in the Huron tribe. This language/culture interest is one of the distinguishing characteristics of the French people, at home and abroad. It is thus unnecessary to convince you of the value of a language and culture integration in the classroom. Instead, I hope to present a perspective on this topic, a concern for a particular view of the relationship between language and culture that is becoming of increasing interest in Languages for Specific Purposes theory, research and curricula.

2 What will be the relationship between LSP and culture in the 1990s? Why is the relationship "special"? I have chosen to discuss two broad topics in my exploration of this question. First, I will examine traditional, "general" approaches to culture found in many foreign language classrooms. Then, I will turn to the "specialness" of the language/ culture relationship in LSP.

\section{The teaching of culture in "general" language classes}

3 Many teachers subscribe to the Whorfian hypothesis that a language cannot be separated from its culture, that the cultures in which languages are embedded are as important to learn as the languages themselves. My own classroom experiences with attempting to learn your language and teaching my own are fairly typical, so I interweave these with my discussion of traditional approaches. 


\section{Culture as artifact}

4 High culture: First of all, there are the aesthetic or "high culture" approaches (Jorden 1992) in which the study of the products is central. To find cultural artifacts, we look to the arts, to the great works which are seen as exemplifying the cultures of various lands. In my French classes in Ohio, for example, I began very early reading simplified texts such as Jean Valjean, a brief narrative from Les Misérables. My teacher, a high culture fan if there ever was one, felt that we must be immediately exposed to the great French writers, even though we couldn't read them in the original. Later, the culture studies in my French classes involved short "tours" of Chartres by film, music by the French masters, and, of course, more literature and philosophy: Pascal, Rousseau, Descartes, Camus. In every French class, the interaction between high culture and language was evident. Through a discussion of high culture artifacts, we were to acquire what was necessary to understand France and its people.

In ESL environments, the presentation of the arts, particularly literature, is again in vogue. Literature is spoken of as "the mirror of national culture" which can acquaint students with the "aesthetic, moral and spiritual values of a nation and the rules of a social system" (Spack 1985: 705). The Whole Language Movement, popular in many parts of the world, has made literature its central focus, as students enjoy, imitate and create within the cultural world that literary study provides (Heald-Taylor 1991). Students whose proficiencies are inadequate to read Faulkner or Hemingway, F. Scott Fitzgerald or Tony Morrison read the stories of new immigrants, slave narratives or tales of the old West.

Low culture. Though "high culture" and its artifacts, particularly works of literature, have been very important to language teaching, "low (or popular) culture" issues have often become essential in environments where adult students may have little time or energy to learn more than what is required for survival. Even in contexts in which there is time to study high culture, low culture may be a topic for the language classrooms because it is of interest to both the language students and the population at large. In my country, for example, many more people know the television shows "Dallas" or "The Cosby Show" but do not know Robert Frost. They are much more familiar with advertisements than with Whistler, Sargeant, Jasper Johns. The comic page is more commonly read than arts reviews; rap is more popular than the Grand Canyon Suite. Thus, in the United States, teachers often draw from popular or "low" culture as they teach English as a second language.

\section{Culture as human behavior}

7 There are other avenues to teaching culture as well. Closely allied with pragmatics and notional-functional syllabi and their descendants is the view of culture as behavior, best known to us through E.T. Hall (1959). Cultured people in particular societies stand a certain distance apart, do or do not use their hands while speaking, display particular kinds of manners at the table, treat their elders in certain ways. To learn "culture", then, it is important to observe how a people behave and to model our behaviors upon what is conceived as appropriate ways of speaking and acting. Language/culture teaching from this perspective begins with observed data and conjectures about what it means to be 
civilized rather than with texts. One of my favorite language-as-behavior texts is Beyond Language (1978), an ESL volume for students coming to study in the United States. In it, students examine interactions with college faculty, with American students, with tradespeople and others to understand the behaviors of the target culture.

\section{Culture as values or symbolic system}

8 So far, I have spoken of two general approaches to the study of culture: viewing it as artifact or product, either of "high" or "low" cultures, and viewing it as observable behavior. Integral to most approaches is an attempt to understand core values and symbols that drive behaviors and influence the artifacts. Not only should we observe the target cultures' approaches to space, to time, to body movement, to food and food sharing, to turn-taking, to the roles of men and women, but we need to ask "why"? What do people in this part of France value that might explain this particular behavior? What symbolic systems drive their responses? Or, as the anthropologist, Clifford Geertz, puts it (1983:155): how can we understand others' "ways of being in the world"?

Gail Robinson, in a volume entitled Crosscultural Understanding (1988) suggests that one important tool for gaining understanding of symbols and values in other cultures is ethnography. She recommends that students (and teachers) examine a cultural topic in depth through participation, observation and informant interview "until [the topic] appears to be exhausted!" (1988: 81) Her approach, drawn directly from work in anthropology, requires rapport between an expert informant within the culture and the student-researcher. It must involve on the students' part a commitment to "researching" the topic, artifact or behavior, creative listening, self-awareness, and intelligent analysis. I find these ethnographic approaches very important, not only to general culture study, but in LSP, as well (Johns 1990).

My own attempts at linguistic and cultural analysis through ethnography have been put to the test in two environments: in Egypt, where we spent two years, and particularly in the People's Republic of China, where I was a Fulbright lecturer. I used to tell my students in China that I was seeing my cultural values in reverse: theirs was the Ying, mine the Yang; theirs the face culture, mine the guilt; theirs the culturally embedded, the group directed; mine the culturally diverse, individualistic. The contradictions between my values and expectations and those of my students and Chinese friends' contributed daily to my culture shock. An ethnographic approach served me well in coming to terms with my shock and the target culture. I looked at the artifacts: the novels, the music, the films and Chinese opera. More importantly, I was a participant observer in an on-going drama in my classroom, where "young Turks" of the post-Cultural Revolution, the former Red Guards, and the old pre-Cultural Revolution faculty were expected to work and study together. I conducted as many in-depth interviews with these students as I could, and I began to sort out for myself the values that drove my students' various ways of being in the world.

11 I have now reviewed some familiar approaches to "general" language and culture interaction: those that focus upon "high" and "low culture" artifacts, and those for which behavior is the core topic. Now, I will turn to LSP and the special relationship suggested in the title of this paper. 


\section{Language and culture in LSP}

\section{LSP teaching? ISP has always been strongly influenced by what is outside of the} classroom and students' future lives: the world of target cultures and the "authentic language" of these cultures (Robinson 1991). Essential to the movement has been "needs assessment" in which the identified target situation is carefully juxtaposed to the language employed there. Current LSP practice is no exception: we are concerned with the artifacts or products, particularly the written discourses; with the behaviors of participants in a culture, particularly those who may influence our students' lives; with specific languages of contexts, and, more recently, with the values that drive discourses. True to form, LSP has not focused upon culture "in general", just as it is not concerned with language "in general". Instead, it concentrates upon linguistic and cultural specificity, upon the specific texts and discourses from identified target communities in which our own groups of students will be operating. Furthermore, we are not interested in these communities and texts "in general", but in the rhetorical situations in which the values of readers and writers and the contexts and texts intersect.

Much of LSP practice, particularly in academic contexts, should begin with examining written or spoken discourses as cultural artifacts, as "genres" that serve communicative purposes within groups of individuals who think and speak of themselves as community members. In my recent article in Les Cahiers de l'APLIUT (December, 1993), I discussed briefly the view of genres as community embedded, a relationship discussed at length by Swales (1990) and by Bhatia (1993), among others. These experts argue that texts give us important clues to the specific cultures to which our students hope to belong, to the discourse communities of their future academic and professional lives. Swales (1990), for example, speaks of genres as a "class of communicative events" serving "shared communicative purposes" (1990: 45-46) of a discourse community. Widdowson (1993) notes that "academic disciplines can be seen as subcultures that manage their communicative affairs in certain ways; in other words, they can be defined in terms of their generic inclinations" (1993: 34).

When LSP practitioners examine high culture texts, then, we see them as artifacts of a community of people who do not necessarily share a first language or geographic location, but share values, goals, ways of being in the world, and, not incidentally, genres that are central to their purposes. What we find when studying the "high cultures" in LSP is that target cultures may be fully as important to the personal or professional lives of community members as the "general" cultures of their language or nation. In this multilingual, international world, individuals in our students' target communities may identify more with (and speak the language of) other computer scientists than with the grocer in their local village; they think of themselves as agronomists or businesspeople as well as citizens. Many primary or core communities to which our students wish to belong cross national, technical and linguistic boundaries; members are driven by the values, the texts and the argot of their group. We can therefore speak of LSP, particularly with a high culture perspective, as "international in scope, but specific in purpose" (Johns \& DudleyEvans 1992).

15 What are the characteristics of an LSP "high culture"? First, cultural membership requires a long and often arduous initiation. A person cannot become a member of a 
university faculty without completing the necessary rites and rituals required. Professionals must not only be educated (correctly!), but they must serve long internships within their professions. Thus, in high LSP cultures, community membership is exclusive and restricted. The language and genres of the communities also exclude: they are written in special registers, composed in the style and lexical shorthand of the community. In their chosen genres, the community readers and writers generally address each other as equals in continuing dialogues of mutual interest. Much knowledge about communities and language is presupposed, thus the texts are opaque to the non-expert but coded for those who belong. As many LSP practitioners have noted, "high culture" texts are the "tip of the iceberg"; so much is understood, so much has been experienced before they are produced that the novices must spend considerable time with community members and their genres before they can begin to gain an "emic", or internal, perspective. An entire area of study, the Sociology of Scientific Knowledge, is devoted to analyzing the values, the texts, the resources and the rituals of high culture communities (Myers 1992), because they are rich and fascinating, and because many of our students want to join them.

The most frequently studied "high culture" text is the research article. There is considerable literature on this genre, its structure, its language, and its production. LSP researchers ask questions such as: Why do research articles in the sciences have certain features? Why are they written in a certain format with particular grammar, lexicon and style? In an interesting series of discussions on the values of disciplines realized in their texts, MacDonald $(1987,1993)$ begins to answer some of these questions. She speaks of scientific writing as "efficient"; a considerably different value from those realized in literary genres, where "belletrism" is central. She claims that efficiency and text brevity claims are found in science because community members have other interests besides the beauty of their prose: they are much more concerned with their laboratories, their methods, and with getting their results published quickly. What we see in scientific genres, then, is not an absence of rhetoric or a lack of thought about language, but the results of a complex process in which research is completed and reported appropriately within a specific "high culture" community.

Many of us, trained in the humanities, look at texts in other disciplinary communities such as those in the sciences and scoff. We find these texts dull, impenetrable, and we turn again to the interesting languages of literature and the arts. However, we cannot scoff at students' target communities and genres in LSP. Instead, we must view scientific communities, like all high culture communities, as deeply rhetorical.

Stylistic choices conspire in the creation of the world as meant by science; organizational choices imitate the approved means of achieving access to the world (Gross 1991: 935).

So far, I have discussed high culture LSP genres, such as the research article in the sciences. I refer to these texts as "high" because they are artifacts of exclusive cultures; cultural membership requires years of initiation into the rites and rituals, the ways of being and speaking, writing and reading in these cultural worlds.

But what does this mean for the average second language speaker who is studying LSP to survive, to work in a factory, to be a service employee in a restaurant or a tourist agency? If we are going to view genres as community artifacts, then we can examine the genres of everyday life to explore language and culture. We must ask these questions: What are the differences between "low" and "high" LSP cultures? Who is the low culture communities? 
What are the relationships between readers and writers in low culture genres? What are the characteristics of the rhetorical situations in which these texts are found?

Let me offer a few answers that my students and I propose so far. Often low-culture genres are much more inclusive than are high culture genres. The community audience is much larger and the language and texts are generally accessible to all who are literate. Community membership can, in many instances, include all of those who are interested in "reading" the text. There are many popular, low culture, genres, of course, including some newspapers, advertisements, popular films, musical hits, signs and pulp magazines. In one of the most influential articles on genre yet published, Carolyn Miller advocates the discussion of this topic at every cultural level, to include the ordinary as well as the aesthetic:

...to consider as potential genres such homely discourse as the letter of recommendation, the user manual, the progress report, the ransom note, the lecture and the white paper...is not to trivialize the study of genre; it is to take seriously the rhetoric in which we are immersed and the situations in which we find ourselves. (1984: 55)

When discussing the differences between these "homely discourses" and those texts I have mentioned in the "high culture" category, Bakhtin refers to the everyday texts as "primary", as relating to "the actual reality and real utterances of others" (1986: 62). He refers to the "high culture" texts or utterances as "secondary" and "complex":

During the process of their formulation, they absorb and digest various primary (simple) genres that have taken form in unmediated speech communication. (1986: 62)

I have chosen to use as texts for the lesson described here a "homely" discourse that is both "everyday" and restricted. It is a "low" culture genre, but the audience is a second language community within the culture. The writers are dominant; their purposes define the text, though the text structure and language are accessible to the audience. As cultures and languages come into contact, in Europe and elsewhere, these types of writerdominant, low culture texts become increasingly common. They can be found in factories, businesses, and government offices or wherever the new speakers of a language are present.

\section{Preparing for an LSP lesson}

Above I argued that in LSP, discourses are viewed as artifacts of specific communities. LSP practitioners are interested in the various contributors to a specific discourse: the speaker/writer and the listener/reader and their community values, the topics and the language, the form and style, and the values that are held by the communities for which the text serves its purposes. A second feature of LSP which will be obvious as the lesson is described, is that language is viewed as in culture. The metalinguistic features, such as the illustrations and format, and the lexis and grammar of texts are culturally determined through consensus in high culture, and often by the dominant speaker/ writers in low culture genres.

In order to present some possibilities for use of this second type of genre, the "low culture" or popular variety, I am using two texts from California, where large Southeast Asian immigrant populations from fishing cultures have settled and are enrolled in survival and vocational LSP courses. There are considerable similarities between my part 
of the world and much of Europe, as guest workers and immigrants come in contact with target languages and communities.

The "low-culture genres" I have chosen were posted in government offices and distributed in language classes in San Diego. In LSP, they have been used as text catalysts in genre/culture/language discussions in beginning proficiency level classrooms. Here is how one instructor taught these texts as embedded in rhetorical situations where the readers and writers, and their communities, interact (see fig. 1).

Fig 1: An LSP lesson

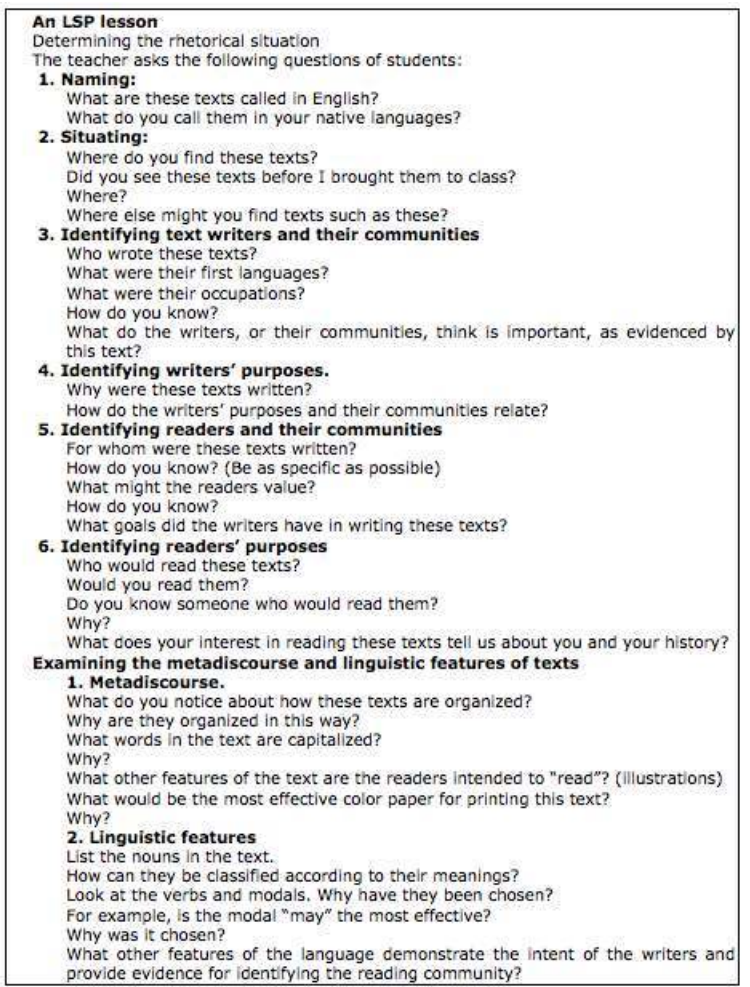

27 The adult school teacher employing this approach found that students were very much interested in the culture/language interaction that was central to this discussion. The students had a great deal to say not only about readers and writers and their communities but about the effectiveness of the texts as "Warning Flyers" in their first and second languages.

\section{Developing genre theories}

The next step in the LSP lesson involved the students' research into warning flyers within their first and second language communities. They brought a few in and analyzed them, using some of the same questions that are listed above. Then, they began to develop theories about the invariant characteristics of this genre: where the texts appear, how they are organized, what types of metadiscourse and linguistic features are somewhat predictable. They built upon their theories through ethnographic interviews of writers and readers of flyers, using the texts as the interview stimuli. 


\section{Completing a genre-related task} approaches to the topic, through "high" and "low" culture artifacts and a study of ingroup behaviors. Then I suggested that in LSP, we are specific about cultures, about language, about texts and about the factors that influence a rhetorical situation. We know in LSP that there is no general language teaching; all teaching should be carefully planned to meet the needs of students and take into consideration the target languages and situations in which the students will be functioning. What is different about LSP, then, is not the special relationship between language and culture, which is the subject of much study, but the special cultures of listeners/readers and speakers/writers, and their languages and the rhetorical situations in which the texts play a role. We recognize that many of the core communities and languages which are most important to our students' lives can be accessed through the genres of these communities, if, in fact, the genres are studied through their potential or real rhetorical contexts. Widdowson (1993: 33). Current LSP practice views the study of this mediation as one of its principal goals. 


\section{BIBLIOGRAPHY}

Bakhtin, M. M. 1986. Speech Genres and Other Late Essays (Trans by V.W. McGee). Austin, TX: University of Texas Press.

Bhatia, V. 1993. Analyzing Genre: Language use in professional contexts. London: Pergamon.

Derewianka, B. 1990. Exploring how Texts Work. Australian Print Group: Maryborough, Victoria.

Geertz, C. 1983. Local Knowledge: Further essays in interpretive anthropology. New York: Basic Books.

Gross, A.G. 1994. "Does the rhetoric of science matter? The case of the floppy-eared rabbits". College English 53, 933-943.

Hall, E.T. 1959. The Silent Language. Garden City, NY: Doubleday and Company.

Halliday, M.A.K. \& Martin, J.R. 1993. Writing Science: Literacy and discursive powers. London: Falmer, Press/University of Pittsburgh Press.

Heald-Taylor, G. 1991. Whole Language Strategies for ESL Students. San Diego, CA: Dominie Press.

Johns, A.M. 1990. "Coherence as a cultural phenomenon: Employing ethnographic principles in the academic milieu". In Connor, U. \& A.M. Johns (eds.), Coherence in Writing: Research and pedagogical perspectives. Alexandria, VA: TESOL.

Johns, A. M. 1993. “ESP around the world: A perspective from the United States". Les Cahiers de l'APLIUT 13/2, 6-15.

Johns, A. M. \& Dudley-Evans, T. 1991. "English for Specific Purposes: International in scope, specific in purpose". TESOL Quarterly 25, 297-314.

Jorden, E. H. 1992. "Culture in the Japanese language classroom: A pedagogical paradox". In Kramsch, C. \& S. McConnell-Ginet (eds.), Text and Context: Cross-disciplinary perspectives on language study. Lexington, MA: D.C. Heath.

Levine, D. \& M. Adelman. 1978. Beyond Language. New York: Prentice-Hall.

MacDonald, Peck, S. 1993. “Competing styles in academic writing about literature". Paper presented at the College Composition and Communication Conference, San Diego, March/April, 1993.

MacDonald, Peck, S. 1987. "Problem definition in academic writing”. In Nash, W. (ed.), The Writing Scholar: Studies in academic rhetoric. Written Communication Annual, Vol. 3. Newbury Park, CA: Sage, 31-62.

Miller, C. 1984. "Genre as social action". Quarterly Journal of Speech 70, 151-67.

Myers, G.A. 1992. “Textbooks and the sociology of scientific knowledge”. English for Specific Purposes 11, 3-18.

Robinson, G.L.N. 1988. Crosscultural Understanding. New York: Prentice-Hall. Robinson, P. 1991. ESP Today: A practitioner's guide. New York: Prentice-Hall.

Spack, R. 1985. “Literature, reading writing, and ESL: Bridging the gap”. TESOL Quarterly 19, 703-726. 
Swales, J. M. 1990. Genre Analysis: English in academic and research settings. New York: Cambridge University Press.

Widdowson, H.G. 1993. “The relevant conditions of language use and learning”. In Krueger, M. \& F. Ryan (eds.), Language and Content: Discipline- and content-based approaches to language study. Lexington, MA: D.C. Heath, 27-36.

\section{ABSTRACTS}

"High" and "low" culture artifacts and related in-group behaviors provide a general framework for a study of the relationship between culture and language. In LSP, we are specific about cultures, about language, about texts and about the factors that influence a rhetorical situation. All LSP teaching should therefore be carefully planned to meet the needs of students, taking into consideration the target situations in which the students will be functioning. What is different about LSP, then, is not the special relationship between language and culture, which is the subject of much study, but the special cultures of listeners/readers and speakers/writers, and their languages and the rhetorical situations in which the texts play a role. Many of the core communities and languages which are most important to our students' lives can be accessed through the genres of these communities, if, in fact, the genres are studied through their potential or real rhetorical contexts.

Le cadre général d'une étude des relations entre langue et culture est fourni par l'examen des produits de la culture "noble» et de la culture "populaire» respectivement, chacune responsable de comportements caractéristique au sein de la communauté. Dans ce que appelons par commodité "langue de spécialité », il y a spécificité culturelle, langagière, textuelle et sociologique. Ces spécificités influent sur la situation rhétorique. En conséquence, dans l'enseignement d'une langue de spécialité, il y a lieu de répondre aux besoins des apprenants en prenant en compte les situations dans lesquelles ils auront à employer la langue apprise. Le lien langue-culture n'est donc pas de nature différente en langue de spécialité : il dépend étroitement des situations de communication. Il convient donc d'étudier de près les genres rhétoriques qui leur correspondent.

INDEX

Mots-clés: communauté, culture noble, culture populaire, genre

Keywords: community, genre, high culture, low culture

\section{AUTHOR}

ANN M. JOHNS

Ann M. Johns is a Professor at San Diego State University (United States). ajohns@cox.net 